\title{
単純 MRIが有用であった大腿深動脈溜の1切除例
}

\author{
岡田 拓 ${ }^{1}$, 竹田 誠 ${ }^{1}$, 安藤 敬 ${ }^{1}$, 秋山 大地 $^{2}$
}

要 旨：大腿深動脈瘤は稀な疾患で無症候性のことが多く早期診断は困難と言われている。3カ月で急速増大 した大腿深動脈瘤患者に対して瘤切除を行ったので報告する。症例は既往に糖尿病性腎症がある75歳男性, 左大腿部の腫脹を主訴に受診し，単純 CTで $63 \mathrm{~mm}$ 大の大腿梁動脈瘤を認めた。単純 MRIで浅大腿動脈から 下腿三分枝まで開存していたことを確認できたため血行再建はせず瘤切除のみ施行した。単純 MRI は治療方針 を決定する上で有用であった。（J Jpn Coll Angiol 2018; 58: 91-94）

Key words: deep femoral artery aneurysm, magnetic resonance imaging

受付：2017年 8 月 16 日 受理：2018年 4 月 4 日 公開： 2018 年 6 月 10 日

\section{序言}

大腿深動脈瘤は稀な疾患であり解剖学的特徵から無症 候性のことが多く早期診断は困難と言われている。しか し破裂や塞栓症などの合併症のリスクが高く，診断され た時点で治療を要することが多い。今回われわれは慢性 腎不全患者に発症した大腿深動脈瘤患者に対して瘤切除 を行ったのでこれを報告する。

\section{症例}

75 歳, 男性。糖尿病性腎症, 高血圧症, 高尿酸血症 にて当院腎臓内科かかりつけの患者。CRP高值 ·貧血 の原因検索で撮影した単純 CTで $27 \mathrm{~mm}$ 大の左大腿深動 脈瘤（DFAA）を指摘されたが経過観察されていた。化 膿性脊椎炎の診断で2力月間の抗生剂加療を行われてい た。DFAAは診断から 1 カ月半後のエコーでは増大はな かったがさらに3カ月後に左大腿近位部の違和感が出 現, 間欠性跛行はなし。単純 CT 施行でDFAA は $63 \mathrm{~mm}$ 大まで拡大していたため当科に紹介となった。

入院時現症 : 身長 $159 \mathrm{~cm}$, 体重 $57 \mathrm{~kg}$, 血圧 124/76 mmHg, 脈 66/分 - 整。心音, 呼吸音以上なし。左鼠加ら大腿内 側にかけて拍動性の瘤を触知。両下肢動脈の拍動は良好 だった。

\footnotetext{
1独立行政法人労働者健康安全機構横浜労災病院心臓血管外科 2 国立循環器病研究センター研究所 doi: $10.7133 /$ jca. $17-00021$
}

\section{(c) BY-NC-ND}

血液検査 : WBC 5200/ $\mu \mathrm{L}, \mathrm{Hb} 9.1 \mathrm{~g} / \mathrm{dL}$, GOT $13 \mathrm{IU} / \mathrm{L}, \mathrm{GPT}$ $5 \mathrm{IU} / \mathrm{L}, \mathrm{CPK} 71 \mathrm{IU} / \mathrm{L}$, BUN $108 \mathrm{mg} / \mathrm{dL}, \mathrm{Cr} 6.3 \mathrm{mg} / \mathrm{dL}$, eGFR $7.5 \mathrm{~mL} / \mathrm{min} / \mathrm{m}^{2}$, CRP $1.5 \mathrm{mg} / \mathrm{dL}$, Glu $102 \mathrm{mg} / \mathrm{dL}, \mathrm{Na} 134 \mathrm{mEq} / \mathrm{L}$, K $5.3 \mathrm{mEq} / \mathrm{L}, \mathrm{Cl} 105 / \mathrm{mEq} / \mathrm{L}$, PT 88\%, PT-INR 1.07, APTT $30.6 \mathrm{sec}$, Fib $221 \mathrm{mg} / \mathrm{dL}$, D-dimer $22.3 \mu \mathrm{g} / \mathrm{dL}$

CT：63 mm大の非破裂性DFAA を認めた（Fig. 1）。

Echo：60 mm大の DFAAを認め, 内部血流方向は不正 で解離も疑われた。SFA近位部は明らかな狭窄を認めな かった。

MRI：浅大腿動脈（SFA）は開存しており，これよ り遠位の下腿三分枝まで描出されていた。大腿深動 脈（DFA）は分岐後約 $3 \mathrm{~cm}$ 末梢で瘤化していた。瘤は $60 \mathrm{~mm}$ 大で中枢側は描出不良で末梢から優位に血液が流 入してきているが, 中枢側が血栓閉塞している所見は認 めなかった（Fig. 2)。

手術所見：鼠径勒帯の直上から $10 \mathrm{~cm}$ 程度 $\mathrm{S}$ 字切開し 皮下組織, リンパ管を結紮切離しながら総大腿動脈,

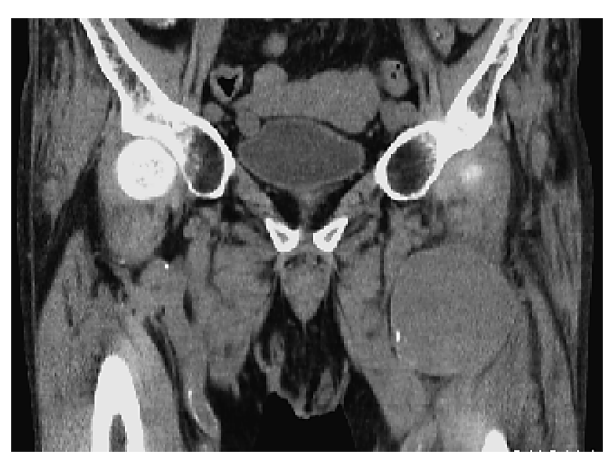

Figure 1 Computed tomography shows left deep femoral artery aneurysm with diameter of $63 \mathrm{~mm}$. 

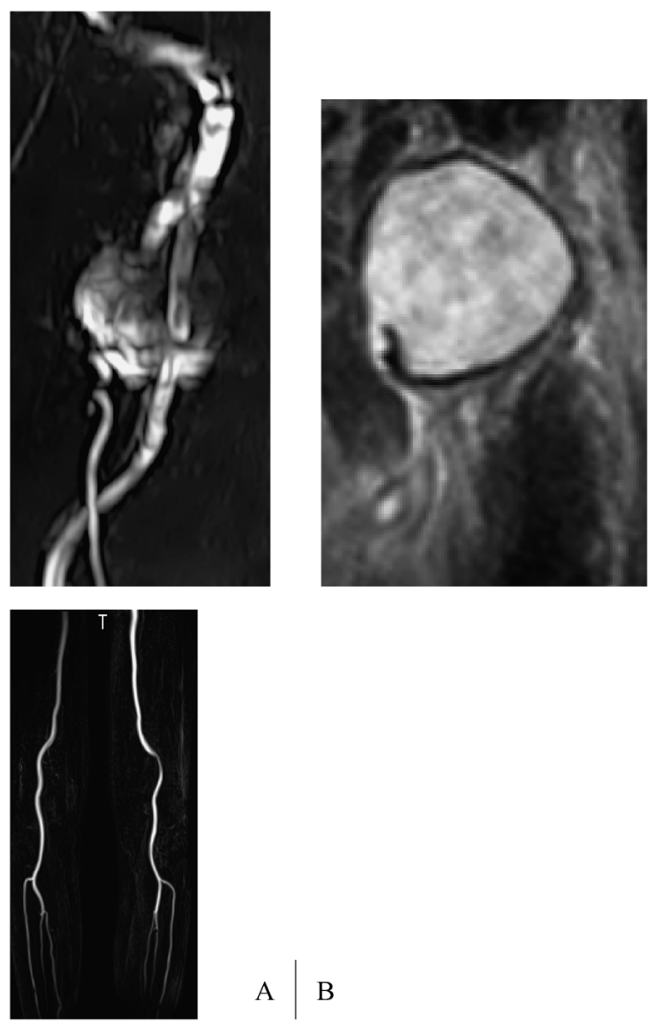

$\mathrm{A} \mid \mathrm{B}$

Figure 2 Magnetic resonance imaging shows patency from superficial femoral artery to peripheral crural artery (A). DFAA is enlarged approximately $3 \mathrm{~cm}$ distal from origin of DFA, and its inflow from distal portion is more dominant than proximal one (B).

SFA, DFAをそれぞれテーピングした。DFAを末梢へ 追っていくと $2 \mathrm{~cm}$ 程度でDFAAに到達, 前面を剝離して 末梢側確保を試みたが筋肉と強固に癒着しており損傷に よる出血や神経損傷の riskが高いと判断し剥離を断念, 血行再建はせず末梢側断端は瘤内より処理する方針とし た。DFA中枢側を結棌した後, 浅大腿静脈の内側縁に 沿い瘤壁を切開した。壁肥厚はなく，内腔は平滑で内膜 は保たれていた。DFA末梢からの backflow は1本のみで これを内腔より縫合止血した。DFAA切開時に癒着して いた静脈から出血したためこれも連続縫合止血した。瘤 壁を開放したまま瘤内拉よび皮下にドレーンを留置して 閉創した。

術後経過：術翌日より歩行開始したが下腿虚血を示唆 する跛行症状は見られなかった。術後12日でドレーン 抜去, 術後17日目で退院となった。

\section{考察}

DFAA は稀な疾患で頻度は末梢動脈瘤の $0.5 \%$ と言われ ている1)。症状は瘤破裂の他に塞栓症, 静脈うつ血, 大 腿神経や腓骨神経障害がある ${ }^{2-4)}$ 。内転筋群間に深く囲 まれていることや, 組織学的にも大腿動脈より筋層に富
み, かつ弾性繊維は少ない特徵があるため拡張しにくい ことが推測されている ${ }^{3)}$ 。解剖学的理由から自覚されに くいため早期発見は困難である。一方, 瘤拡大は早いと 言われているがその機序は不明である ${ }^{5)}$ 。瘤径の経時的 変化について記載している報告は散見されないが, 本症 例では定期的に画像検査を行っていたため瘤拡大の推 移を観察記録することができた。つまりDFAは2年間で $27 \mathrm{~mm}$ 大に瘤化し，そのわずか 3 力月後には $60 \mathrm{~mm}$ 大ま で急速拡大していた。経過中に化膿性脊椎炎を併発して おり急速拡大の原因として瘤の感染が考えられるが, 皮 膚の熱感や発赤のエピソードはなく形態も真性瘤・紡錘 状で感染瘤の根拠に乏しかった。その他, 外傷や過度の 運動の既往もなくやはり原因は断定できなかった。

診断にはエコー, 血管造影, 造影 $\mathrm{CT}$ な゙が有効 で6-8), 血行再建の必要性を評価する上でSFA, DFA 領域 の血流評価が必須になる。血管エコーは簡便・低侵襲で あるが本症例では疼痛や下肢浮腫が強く DFAA や下肢動 脈全体の詳細な評価が困難であった。また糖尿病性腎 症が既往にあり造影剤は使用できず，非造影MRIで評 価せざるを得なかった。SFAが開存していること，また DFAA は中枢側よりも末梢側からの逆行性流入が優位で あったことから血行再建は必須ではないと判断した。術 中所見でも瘤を切開すると末梢から back flow が確認で きたため血行再建はせず, 術後も虚血を示唆する所見は 出現しなかった。非造影MRIはとくに造影剤使用が困 難な症例において DFAAの評価方法として一つの選択肢 になると思われた。

手術適応に関しては瘤径 $20 \mathrm{~mm}$ 以上とする考えが一般 的だが9)，35 mm以下では合併症が起きる可能性は低く 無症候性であれば $35 \mathrm{~mm}$ 以上が治療適応という意見もあ $り^{10)}$, 患者状態や瘤径, 瘤拡大の速度, そして合併症 の有無を基に症例ごとに治療適応を判断する必要があ

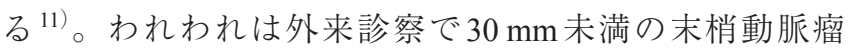
なら半年後にCT撮影し, サイズ変化なければ一年後の CT撮影で対応していた。本症例経験以後, しばらく 3 カ月ごとのCT撮影も考慮するようにしてはいるが, 急 速増大の機序が明らかでない以上その線引きは難しい。

治療は瘤破裂や塞栓症の予防のために瘤切除を行い, 必要に応じて血行再建を行う。SFA 以遠に狭窄病変があ る場合は血行再建が必要である。またDFAは動脈硬化 変化が起きにくいため将来的な救肢の観点からすると やはりDFAの血流を温存することにメリットはある ${ }^{12)} 。$ 本症例のようにSFAが開存していれば血行再建は必須で はないが，糖尿病性腎症の患者であり今後下肢動脈に狭 
窄が起きる可能性があることを踏まえると血行再建の追 加が望ましかった。しかし瘤が周囲と癒着しており, 副 損傷を懸念してDFA 末梢側を確保できず血行再建を断 念した。瘤を開放した後にバルーンカテーテルを用いて

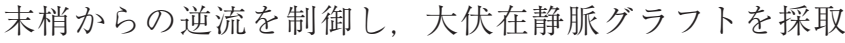
し, intraluminal法で剥離を要さずに吻合するなど工夫し て血行再建すべきたったと反省した。

\section{結語}

糖尿病性腎症を既往にもつDFAA 症例を経験した。造 影剤による腎機能障害が懸念される症例に対して単純 MRI は治療方針を決定する上で有効であった。

\section{利益相反}

共著者全員に利益相反はない。

\section{文献}

1) Roseman JM, Wyche D: True aneurysm of the profunda femoris artery: literature review, differential diagnosis, management. J Cardiovasc Surg (Torino) 1987; 28: 701-705

2) Harbuzariu C, Duncan AA, Bower TC, et al: Profunda femoris artery aneurysms: association with aneurismal disease and limb ischemia. J Vasc Surg 2008; 47: 31-35

3) Posner SR, Wilensky J, Dimick J, et al: A true aneurysm of the profunda femoris artery: a case report and review of the English language literature. Ann Vasc Surg 2004; 18: 740-746
4) Markland CG: Primary atheroscrelotic aneurysm of the profunda femoris artery associated with distal embolization. Ann Vasc Surg 1989; 3: 389-391

5) Tait WF, Vohra RK, Carr HM, et al: True profunda femoris aneurysms: are they more dangerous than other atherosclerotic aneurysms of the femoropopliteal segment? Ann Vasc Surg 1991; 5: 92-95

6) Toda R, Yuda T, Watanabe S, et al: Surgical repair of a solitary deep femoral arterial aneurysm: report of two cases. Surg Today 2000; 30: 481-483

7) Yahel J, Witz M: Isolated true atherosclerotic aneurysms of the deep femoral artery. Case report and literature review. J Cardiovasc Surg (Torino) 1996; 37: 17-20

8) 野村陽平, 堀大治郎, 野口権一郎, 他: 大腿深動脈瘤 破裂の 1 手術症例。日血外会誌 2012; 21: 791-794

9) Tsilimparis N, Faber E, Zindler K, et al: Aneurysms of the deep femoral artery: a systematic review of literature. Zentralbl Chir 2012; 137: 430-435

10) Lawrence PF, Harlander-Locke MP, Oderich GS, et al: The current management of isolated degenerative femoral artery aneurysms is too aggressive for their natural history. J Vasc Surg 2014; 59: 343-349

11) Igari $K$, Kudo $T$, Toyofuku $T$, et al: Surgical treatment for profunda femoris artery aneurysms: five case reports. Case Rep Vasc Med 2015; 2015: 375278

12) Gemayel G, Mugnai D, Khabiri E, et al: Isolated bilateral profunda femoris artery aneurysm. Ann Vasc Surg 2010; 24: 824.e11-e13 


\title{
A Case of Resection of Rapid-increasing Deep Femoral Artery Aneurysm
}

\author{
Hiroshi Okada ${ }^{1}$, Makoto Takeda ${ }^{1}$, Takashi Andoํㅡㄹ , and Daichi Akiyama² \\ ${ }^{1}$ Department of Cardiovascular Surgery, Yokohama Rosai Hospital, Kanagawa, Japan \\ ${ }^{2}$ National Cerebral and Cardiovascular Center Resarch Institute, Osaka, Japan
}

Key words: deep femoral artery aneurysm, magnetic resonance imaging

Deep femoral artery aneurysms (DFAA) are rare and their diagnosis is difficult in the early stage. We report a case of DFAA with rapid enlargement for three months. A 72-year-old man with chronic renal failure was admitted with a complaint of pain in the left medial thigh swollen. Computed tomography confirmed a left DFAA with diameter of $63 \mathrm{~mm}$. Because magnetic resonance imaging (MRI) shows patency from superficial femoral artery to peripheral crural artery, we performed only resection of the aneurysm without re-vascularization of the distal deep femoral artery. MRI is useful to decide therapeutic strategy of DFAA.

(J Jpn Coll Angiol 2018; 58: 91-94)

Online publication June 10, 2018 